\title{
Influence of Nothofagus bark pH on the lichen and bryophytes richness, Central Chile
}

\section{Influencia del pH de la corteza de Nothofagus sobre la riqueza de líquenes y briófitos, Chile central}

\author{
Iris Pereira ${ }^{1}$, Frank Müller $^{2} \&$ Mario Moya ${ }^{3}$ \\ ${ }^{1}$ Instituto de Biología Vegetal y Biotecnología, Universidad de Talca, Casilla 747, Talca. \\ ${ }^{2}$ Institut für Botanik, Fachrichtung Biologie, Fakultät Mathematik und Naturwissenschaften,Technische Universität Dresden, \\ Mommsenstrasse 13, 01062 Dresden. Alemania. \\ ${ }^{3}$ Departamento de Ciencias Vegetales, Laboratorio Biotecnología Vegetal, Pontificia Universidad Católica de Chile, Vicuña \\ Mackenna 4860, Santiago, Chile. \\ ipereira@utalca.cl; frank.mueller@tu-dresden.de; mrmoya@uc.cl
}

\begin{abstract}
The influence of the $\mathrm{pH}$ of the bark of two tree species belonging at Nothofagus genus on the lichen and bryophyte richness was studied. The tree species considered for this study were: $N$. dombeyi and N. macracarpa situated in two pre-Andean localities; one in the "Radal Siete Tazas" National Reserve and the other in the "Altos de Lircay" National Reserve, Central Chile. In each locality, a total of 20 phorophytes were examined: $10 \mathrm{~N}$. dombeyi and $10 \mathrm{~N}$. obliqua. In each phorophyte, the total lichens and bryophytes were inventoried, the diameter of each one of the phorophytes was measured at breast height (DHA) and, in addition, $10 \mathrm{~g}$ of bark were extracted in order to check the $\mathrm{pH}$. The $\mathrm{pH}$ of the bark was determined by means of the Mezger's method (1996) and afterwards related to the lichen and bryophyte richness found in the phorophytes of each tree species sampled in both localities. In both localities, the $\mathrm{pH}$ of bark of the $N$. dombeyi phorophytes was markedly more acidic than the one of the $N$. obliqua. Statistical analyses show a significant difference between the $\mathrm{pH}$ of one species and other. The $\mathrm{pH}$ of the barks of $N$. dombeyi and $N$. obliqua phorophytes, in both localities, not correlated with the richness of the different groups (lichens, mosses and liverworts). However, according to the inventories carried, it observed that some species of lichens have a close relation with the $\mathrm{pH}$ of the bark of one or other of the two tree species studied and only a low percentage of them were indifferent to $\mathrm{pH}$ of the phorophytes. The mosses preferred bark with $\mathrm{pH}$ near to neutrality such as those of $N$. obliqua, while the liverworts preferred bark were more acid, such as the ones of $N$. dombeyi.
\end{abstract}

KeYwords: Native forest, Chile, pH of the bark of Nothofagus, "Radal Siete Tazas”, "Altos de Lircay”, Maule Region.

\section{RESUMEN}

Se estudió la influencia del pH de las cortezas de dos especies arbóreas del género Nothofagus sobre la riqueza de líquenes y briófitos. Las especies arbóreas consideradas en este estudio fueron: $N$. dombeyi y N. obliqua situadas en dos localidades preandinas: una dentro del Reserva Nacional "Radal Siete Tazas" y la otra en la Reserva Nacional "Altos de Lircay", Chile central. En cada localidad, un total de 20 forófitos fueron examinados: $10 \mathrm{~N}$. dombeyi y $10 \mathrm{~N}$. obliqua. En cada forófito, el total de líquenes y briófitos fue inventariado, el diámetro de cada uno de los forófitos fue medido a la altura del DAP y además $10 \mathrm{~g}$ de corteza por forófito fue extraída para verificación del $\mathrm{pH}$. El pH de las cortezas fue determinado por medio del método de Mezger (1996) y más tarde fue relacionado con la riqueza de líquenes y briófitos encontrada en los forófitos muestreados de cada especie arbórea, en ambas localidades. En ambas localidades, el pH de las cortezas de los forófitos de $N$. dombeyi fueron más ácidas que aquellas de $N$. obliqua. Los análisis estadísticos análisis revelan una diferencia estadísticamente significativa entre el $\mathrm{pH}$ de una especie a otra. El pH de la corteza de forófitos de $N$. dombeyi y $N$. obliqua, en ambas localidades, no se correlaciona con la riqueza de los diferentes grupos (líquenes, musgos y hepáticas) analizados, sin embargo, y de acuerdo a los inventarios realizados, se pudo observar que algunas especies de líquenes presenta una estrecha relación con el $\mathrm{pH}$ de las cortezas de una u otra de las especies arbóreas estudiadas y sólo un bajo porcentaje de éstas se mostraron indiferentes al $\mathrm{pH}$ de los forófitos. Los musgos prefieren cortezas más cercanas a la neutralidad como las de $N$. obliqua, mientras que las hepáticas prefieren cortezas más ácidas como las de $N$. dombeyi.

Palabras clave: Bosque nativo, Chile, pH de las cortezas de Nothofagus, "Radal Siete Tazas", “Altos de Lircay”, Región del Maule. 


\section{INTRODUCTION}

In the forestry ecosystems, the composition of epiphytic bryophyte and lichen species varies depending on tree species and it is highly related with bark chemical and physical properties (Barkmann 1958, Hawksworth \& Hill 1984, Van Herk 2001, Mezaka et al. 2008, 2012). Others factors that can contribute to vary the pattern of species that occurs in the different phorophytes that compose the natural forestry ecosystems are the age tree, bark crevice depth (Snäll et al. 2004, Gustafsson \& Eriksson 1995) likewise the condition associated to the duration of the leaves of the phorophytes (Barkman 1958). Nevertheless, the $\mathrm{pH}$ of tree bark and the susceptibility to toxic substances seems to be two major primary factors affecting epiphytic lichen composition (Jüriado et al. 2009, Larsen et al. 2006).

Lichen and bryophyte richness have been the subject of various studies inside and outside protected areas in the Maule Region (Pereira \& San Martín 1998, Pereira et al. 1999, Müller \& Pereira 2006, Pereira et al. 2006), in particular their association with endemic tree species with a vulnerable or endangered conservation status in the Chilean native forests of Mediterranean climate.

In Europe, it is well known that the bark $\mathrm{pH}$ of the trees comprising the forests play an important role in the lichen and bryophyte richness (Kuusinen 1996). Also there is abundant literature to worldwide that indicates that different environmental factors or anthropogenic perturbations in the forests can change drastically the $\mathrm{pH}$ of the bark of the different phorophytes of the forest and, consequently, can alter the richness of both groups (Van Herk 2001). Up to now, there has not been any reported work in Chile that relates the richness of both groups to the bark $\mathrm{pH}$ of tree species that are part the native forest in National Parks and/or Reserves. This type of information could be useful, particularly in terms of lichen ecology. Also it could utilized as a tool to assess indirectly the dynamics of the health status of the Chilean temperate native forests due to that a change of bark $\mathrm{pH}$ in the phorophytes could reflect a change in the lichen and bryophytes richness. In this study, we proposed the following objectives: a) to know the lichen and bryophytes richness in two endemic tree species of genus Nothofagus, b) to measure of the $\mathrm{pH}$ of the bark in phorophytes of both tree species and c) to relate the lichen and bryophytes richness with the $\mathrm{pH}$ of the bark of both arboreal species.

\section{MATERIALS AND METHODS}

AREA STUDY

The study area (Fig. 1) comprised two localities situated in the pre-Andean zone of Maule Region. The first locality, Parque Inglés, at $1.100 \mathrm{~m}$ situated in "Radal Siete Tazas"
National Reserve $\left(35^{\circ} 27^{\prime} \mathrm{S} ; 71^{\circ} 02^{\prime} \mathrm{W}\right.$ ) (Fig 1) and the second in the protected area of the National Reserve "Altos de Lircay", at $1150 \mathrm{~m}\left(35^{\circ} 36^{\prime} \mathrm{S} ; 71^{\circ} 05^{\prime} \mathrm{W}\right)$ (Fig. 1). Forests are part of forest ecosystems located in the Mediterranean climate of central Chile. In both localities coexist deciduous and evergreen species. N. obliqua (Mirb.) Oerst. is a deciduous tree species while $N$. dombeyi (Mirb.) Oerst. is an evergreen. Both tree species are dominant in the forests of both localities.

\section{Collection of SAMPles AND DETERMinAtion OF TREE-TRUnK} DIAMETERS

In each locality, a total 20 phorophytes selected randomly were sampled, $10 \mathrm{~N}$. dombeyi and $10 \mathrm{~N}$. obliqua.

Bark was scraped from the trunk using a large knife, taking sure not to damage the underlying living tissues of the tree. In each phorophyte, the total of lichen and bryophytes were inventoried on the total area of each sampled trunk between 0.5 and $1.50 \mathrm{~m}$ and $10 \mathrm{~g}$ of bark were extracted with the aim of determining the $\mathrm{pH}$. All samples were collected from living parts of the tree and placed in paper bags, on which tree number and name were recorded. Trunk diameters at breast height $(\mathrm{DBH}=1.5 \mathrm{~m})$ were measured for each tree by means of a Lufkin girth bands and voucher specimens of lichens and bryophytes were gathered for their later identification.

\section{DETERMINATION OF THE PH OF BARKS}

For the determination of $\mathrm{pH}$ of barks, the Mezger's (1996) method was used: $2 \mathrm{~g}$ of bark were crumbled and left in soaking in $30 \mathrm{ml}$ of distilled water for $24 \mathrm{~h}$ adjusting the $\mathrm{pH}$ to 7.0. This procedure was repeated three times for each phorophyte with the purpose of obtaining a mean value. After of $24 \mathrm{~h}, \mathrm{pH}$ was measured by means an Extech model Oyster $\mathrm{pH}$ meter.

\section{TAXONOMIC IDENTIFICATION OF THE SPECIES}

The taxonomic identification was made for those species that not were determined in the field. For the case of lichens, vegetative characters of the thallus were analysed by means of a Kyoma binocular stereoscope and the reproductive characters of the fungi by means a binocular microscope Nikon model Optiphot equipped with a microphotographic camera with graduated ocular. Spot tests of thallus and some structures of the reproductive apparatus were analyzed (Walker \& James 1980). For the collection of bryophytes, the material was obtained at random and manually. For the identification of the species of mosses, vegetative and reproductive structures of the sporophyte and gametophyte phases were analysed. In the case of the liverworts were mainly used vegetative and reproductive structures of the sporophyte. The material studied (lichens and bryophytes) will be deposited in the future herbarium of the University of Talca. 


\section{STATistical anAlysis}

Besides ANOVA test and Simple regression was used for establish correlation amongst bark $\mathrm{pH}$ and species phorophytes.

For the statistical analysis of the results, it was used the Statgraphics Centurion XV software, Version 15.2.11 in order to establish relationships between bryophytes and lichen richness and the diameter of the phorophytes in both localities.

\section{RESULTS}

In the four following tables, are shown the lichen and bryophyte species associated at the bark $\mathrm{pH}$ of the phorophytes and its respective diameter in two Nothofagus species situated in two localities in the pre-Andean part of central Chile.

Tables I and II summarise the results found in Parque Inglés, in the "Radal Siete Tazas" National Reserve (Fig. 1) and Tables III and IV, those of the "Altos de Lircay" National Reserve (Fig. 1) of each one of the tree species analysed.

The total number of lichen species found in the Parque Inglés in "Radal Siete Tazas" National Reserve on $N$. dombeyi and in the "Altos de Lircay" National Reserve was 16 and 19 respectively. The total number of lichen species found on N. obliqua in the Parque Inglés in "Radal Siete Tazas National Reserve and the "Altos de Lircay" National Reserve was 19.

In both localities, $N$. dombeyi bark showed a $\mathrm{pH}$ range markedly more lower than that of $N$. obliqua. In the Parque Inglés in "Radal Siete Tazas" National Reserve, the $N$. dombeyi bark showed a $\mathrm{pH}$ range of 4.06-5.17 and "Altos de Lircay" National Reserve, 4.20-5.21 while that N. obliqua showed a range of 5.06-6.25 and 5.08-5.90 respectively (Tables I, II, III and IV). According to statistical analysis, the $\mathrm{pH}$ bark of both phorophytes was significantly different. The value $p$ of the proof $F$ result to be is inferior at 0.05 , which would indicate that there is a significant statistical difference between the $\mathrm{pH}$ of a tree species to other with respect to its barks analyzed (Fig. 2).

Some of the lichen species found in the bark of $N$. dombeyi phorophytes in both localities showed a remarked affinity to the $\mathrm{pH}$, such as Bryoria chalybeiformis, Graphina sp., Hypogymnia subphysodes, Hypotrachyna sinuosa, Parmotrema perlatum, Platismatia glauca, Rinodina sophodes and Tuckermannopsis chlorophylla.

In addition, there were species that showed a notable preference for the N. obliqua bark, for example: Caloplaca ferruginea, Collema nigrescens, Flavoparmelia rutidota, Haemathomma chilenum, Lecanora albella, L. argentata, L. chlarotera and Lecidella elaeochroma.

In view of the low diversity of bryophytes observed in phorophytes of both tree species, in both localities, and the lack of selectivity of them in relation to tree species, it suggests that the bryophyte species found have a greater range of tolerance to $\mathrm{pH}$ than the lichen species (Tables I, II, III and IV).

The richness of moss on $N$. obliqua was higher than that on $N$. dombeyi, while that the liverworts was slightly higher on $N$. dombeyi that on N. obliqua, in both localities studied.

The mean of the diameter of the phorophytes for $N$. dombeyi in the Park Inglés in "Radal Siete Tazas" National Reserve and in the "Altos de Lircay" National Reserve was 41.2 and $32.6 \mathrm{~cm}$ respectively while the mean of the diameter of $N$. obliqua was 29.2 and $20 \mathrm{~cm}$ respectively.

According to data obtained from the software Statgraphics Centurion XV statistical tests indicate with $95 \%$ confidence level, no significant difference between the diameter of phorophytes detected and the number of species observed (Fig. 3).

\section{DISCUSSION}

In general, it is known that the composition of lichen communities can vary according to bark chemistry and habitat conditions such as age and history of the woodland, forest productivity, aspect and climate (Ihlen et al. 2011).

The floristic composition of epiphytic lichen communities on Nothofagus species in Chile has been determined by substrate qualities such as: age and texture bark of the phorophytes (Pereira \& San Martín 1998, Pereira et al. 1999). A similar situation has been described for epiphytic bryophyte and lichen composition in a Fagus forest (Aude \& Poulden 2000).

Based on the results obtained here, it was found that the pattern of $\mathrm{pH}$ range is specific for each tree species, independently of the localities studied. This could indicate that bark of these tree species still shows their natural pattern of $\mathrm{pH}$ in these areas protected. Therefore, it will be interesting to contrast these results with the bark $\mathrm{pH}$ of both tree species in areas not protected and correlate with bryophyte and lichen richness. The current results showing the bark $\mathrm{pH}$ of these two Nothofagus tree species are the first ones to be reported from Chile.

In spite of that some lichen species showed a marked preference for a slightly acid habitat while others opted for bark pH's near to neutrality. Lichen species such as: Bryoria chalybeiformis, Graphina sp., Hypogymnia subphysodes, Hypotrachyna sinuosa, Platismatia glauca, Rinodina sophodes and Tuckermannopsis chlorophylla are exclusive to the bark of $N$. dombeyi. Some of these species, such as Rinodina sophodes and Plastimatia glauca, have also been found in other latitudes of Mediterranean climate growing on bark of certain species of Quercus that have range of pH similar at to $N$. dombeyi bark (Öztürk \& Oran 2011). 


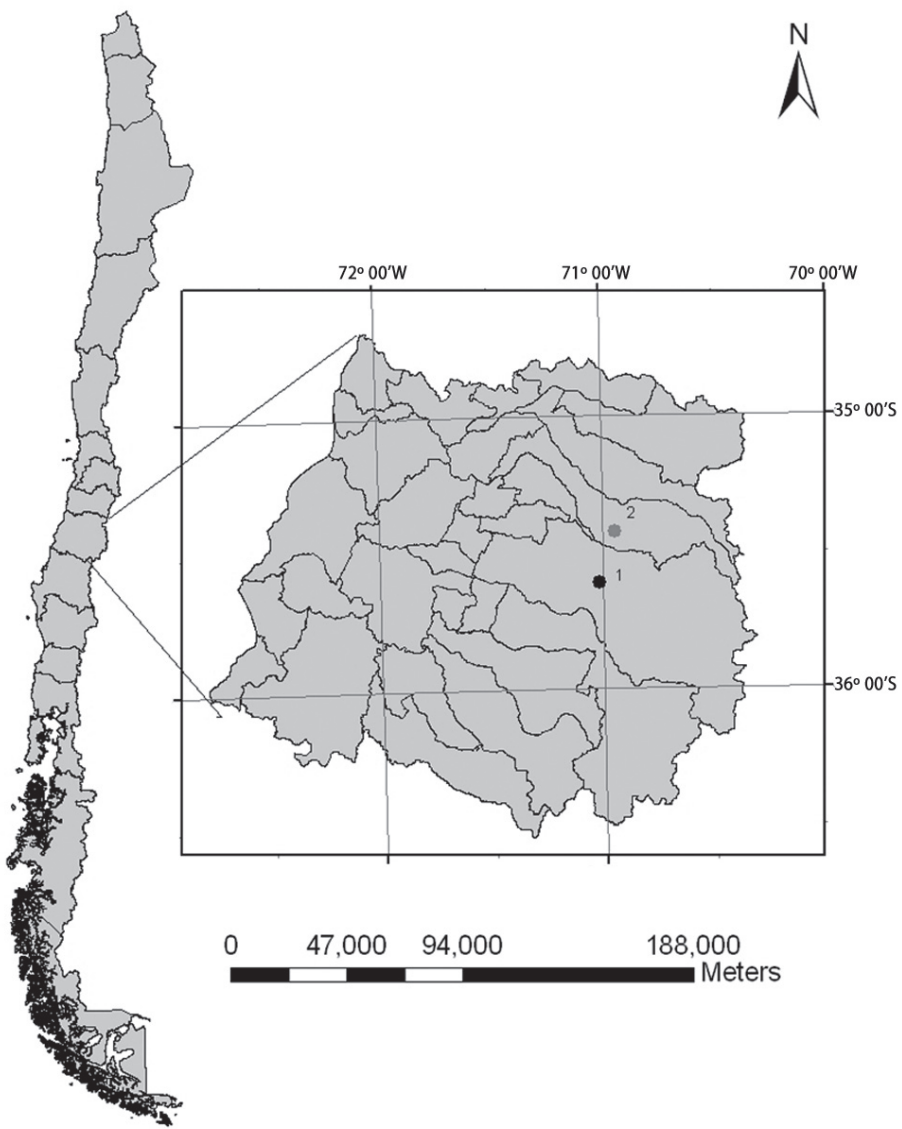

Figure 1: Geographical position of the National Reserves in the Maule Region. 1.- "Altos de Lircay" and 2.- "Radal Siete Tazas". FigURA 1: Localización geográfica las reservas nacionales en la región del Maule: 1.- "Altos de Lircay” y 2.- "Radal Siete Tazas".

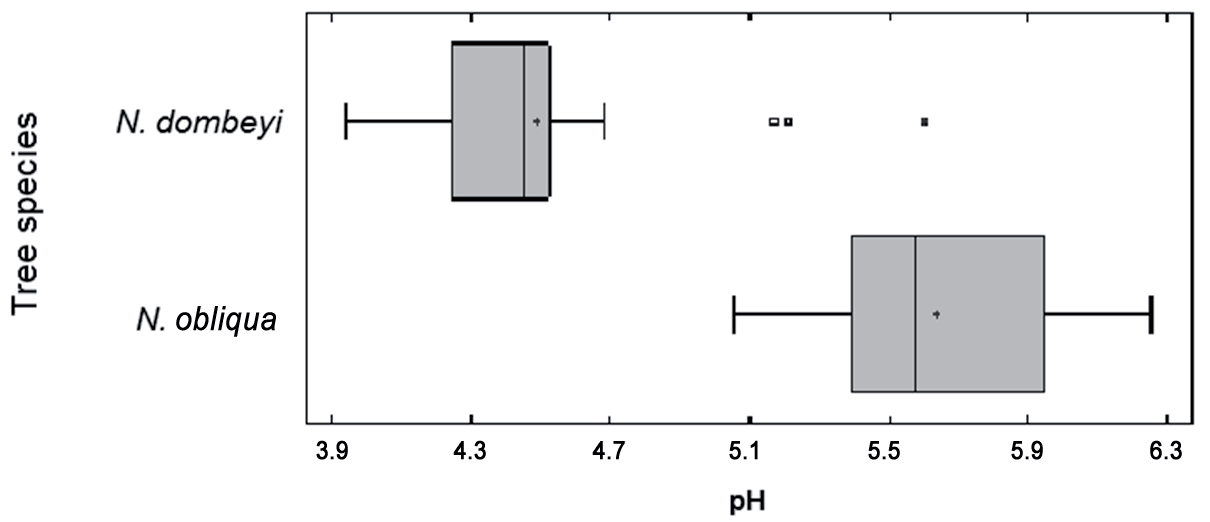

FIGURE 2: Relationships between the $\mathrm{pH}$ of the bark of trees and the tree species.

FIGURA 2: Relación entre el pH de las cortezas de los árboles y la especie arbórea. 
TABLE I. Relationship among richness of lichen and bryophytes, bark pH and diameter of phorophytes in Nothofagus dombeyi in the Parque Inglés, "Radal Siete Tazas National Reserve.

TABLA I. Relación entre la riqueza de líquenes y briófitos, pH de la corteza y diámetro de los forófitos en Nothofagus dombeyi en el Parque Inglés, "Reserva Nacional Radal Siete Tazas".

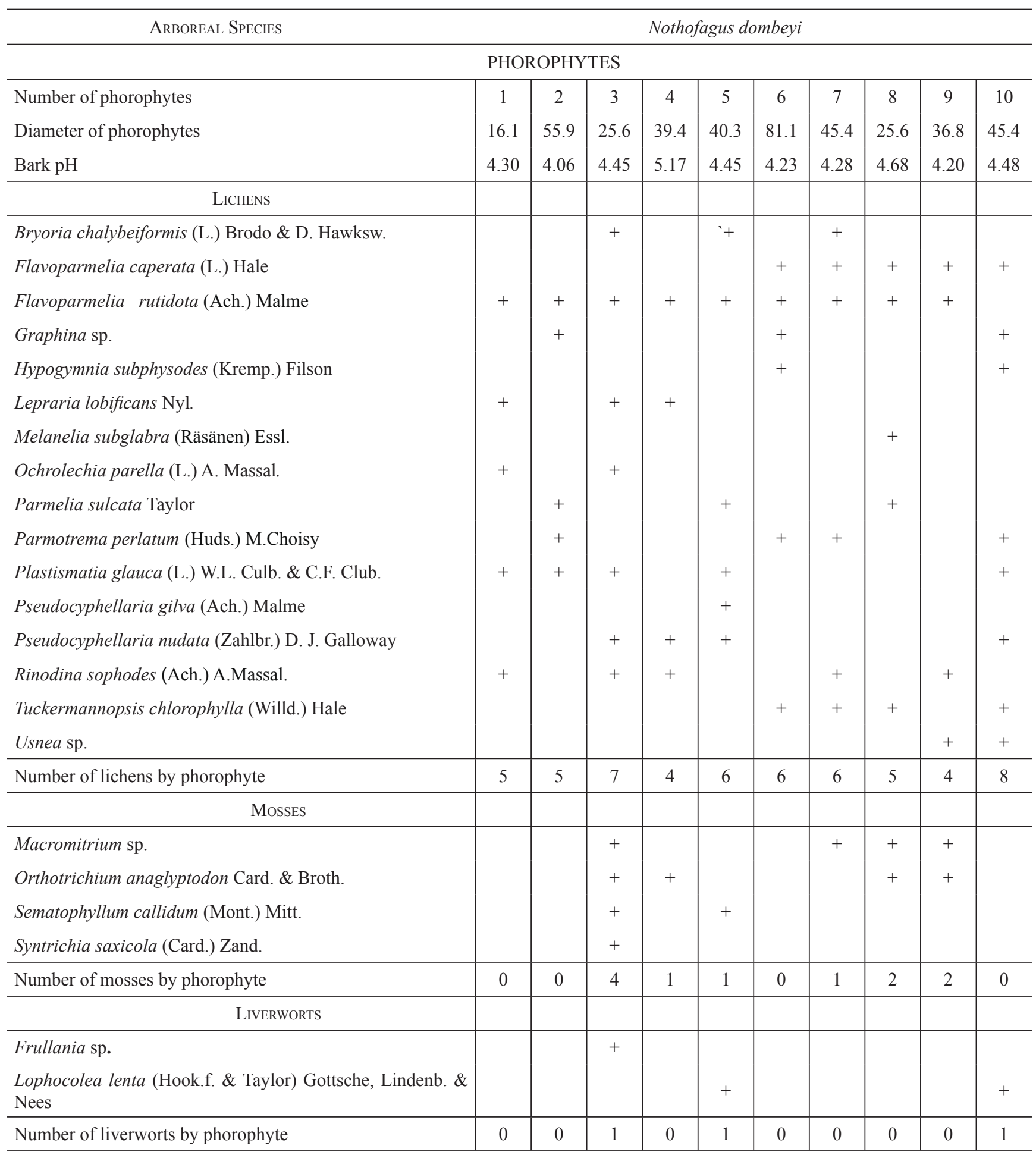

+: presence/ presencia. 
TABLE II. Relationship among richness of lichen and bryophyte, bark pH and diameter of phorophytes in Nothofagus obliqua in the Parque Inglés, "Radal Siete Tazas" National Reserve.

TABLA II. Relación entre la riqueza de líquenes y briófitos, pH de la corteza y diámetro de los forófitos en Nothofagus obliqua en el Parque Inglés, "Reserva Nacional Radal Siete Tazas".

\begin{tabular}{|c|c|c|c|c|c|c|c|c|c|c|}
\hline Arboreal Species & \multicolumn{10}{|c|}{ Nothofagus obliqua } \\
\hline & \multicolumn{10}{|c|}{ PHOROPHYTES } \\
\hline Number of phorophytes & 1 & 2 & 3 & 4 & 5 & 6 & 7 & 8 & 9 & 10 \\
\hline Diameter of phorophytes (cm) & 23 & 22.5 & 39.1 & 33.3 & 14.2 & 47.3 & 40.6 & 20.6 & 30.4 & 21.2 \\
\hline Bark pH & 5.34 & 5.42 & 6.22 & 6.10 & 5.06 & 6.16 & 5.99 & 5.46 & 36.25 & 5.37 \\
\hline \multicolumn{11}{|l|}{ LICHENS } \\
\hline Caloplaca ferruginea (Hudson) Th. Fr. & & & + & & + & & & + & & + \\
\hline Candelariella xanthostigma (Pers.) Lettau & + & & & & + & & & + & & + \\
\hline Collera nigrescens (Huds.) DC. & + & & + & & & + & + & + & + & \\
\hline Flavoparmelia rutidota (Hook. f. \& Taylor) Hale & + & + & & & + & & & + & & + \\
\hline Hypotrahcyna sinuosa (Sm.) Hale & + & + & & & + & & & + & & + \\
\hline Lecanora albella (Pers.) Ach. & & & & & + & & & & & + \\
\hline Lecanora chlarotera Nyl. & & & & & + & & & + & & \\
\hline Lecanora argentata (Ach.) Malme & & + & & + & & & & & & + \\
\hline Lecidella elaeochroma (Ach.) Choisy & & & & & + & & & + & & + \\
\hline Lepraria lobificans Nyl. & & & + & + & & + & + & & + & \\
\hline Melanelia subglabra (Räsänen) Essl. & & + & & & & & & + & & + \\
\hline Parmotrema perlatum (Huds.) M.Choisy & & & & & + & & & & & \\
\hline Physcia adscendens (Fr.) H. Olivier & + & + & & & + & & + & + & + & \\
\hline Physcia caesia (Hoffm.) Fûrnr. & & & & & & & & + & & \\
\hline Pseudocyphellaria gilva (Ach.) Malme & & & & & & & & & & + \\
\hline Pseudocyphellaria nudata (Zahlbr.) D. J. Galloway & & & + & & & + & + & + & + & \\
\hline Rimelia reticulata (Taylor) Hale \& A. Fletcher & & + & & + & & & & & & \\
\hline Teloschistes flavicans (Sw.) Norman & + & & & & + & & & & & \\
\hline Usnea pusilla (Räsänen) Räsänen & + & + & & & + & & & & & + \\
\hline Number of lichens by phorophyte & 7 & 7 & 4 & 3 & 11 & 3 & 4 & 11 & 4 & 10 \\
\hline \multicolumn{11}{|l|}{ Mosses } \\
\hline Grimmia trichophylla Grez. & + & & & & & & & & & \\
\hline Orthotrichium anaglyptodon Card. \& Broth. & + & + & + & + & + & + & + & + & + & + \\
\hline Orthotrichium sp. & & & & & & & & & & + \\
\hline Orthotrichium cf. hortense Boswell & & + & & & & & & & & \\
\hline Syntrichia cf. laevipila Brid. & & & + & + & & & + & & + & \\
\hline Syntrichia saxicola (Card.) Zand. & & & + & & + & + & + & + & + & + \\
\hline Syntrichia cf. virescens (De Not.) Ochyra & & & & + & & & & & & \\
\hline Number of mosses by phorophyte & 2 & 2 & 3 & 3 & 2 & 2 & 3 & 2 & 3 & 3 \\
\hline \multicolumn{11}{|l|}{ LIVERWORTS } \\
\hline Frullania sp. & & & & & & & & + & + & \\
\hline Number of liverworts by phorophyte & 0 & 0 & 0 & 0 & 0 & 0 & 0 & 1 & 1 & 0 \\
\hline
\end{tabular}


TABLE III. Relationship among the richness lichen and bryophyte, bark pH and diameter of phorophytes in Nothofagus dombeyi in the Protected Area, “Altos de Lircay” National Reserve.

TABLA III. Relación entre la riqueza de líquenes y briófitos, pH de la corteza y diámetro de forófitos en Nothofagus dombeyi en el área protegida "Reserva Nacional Altos de Lircay".

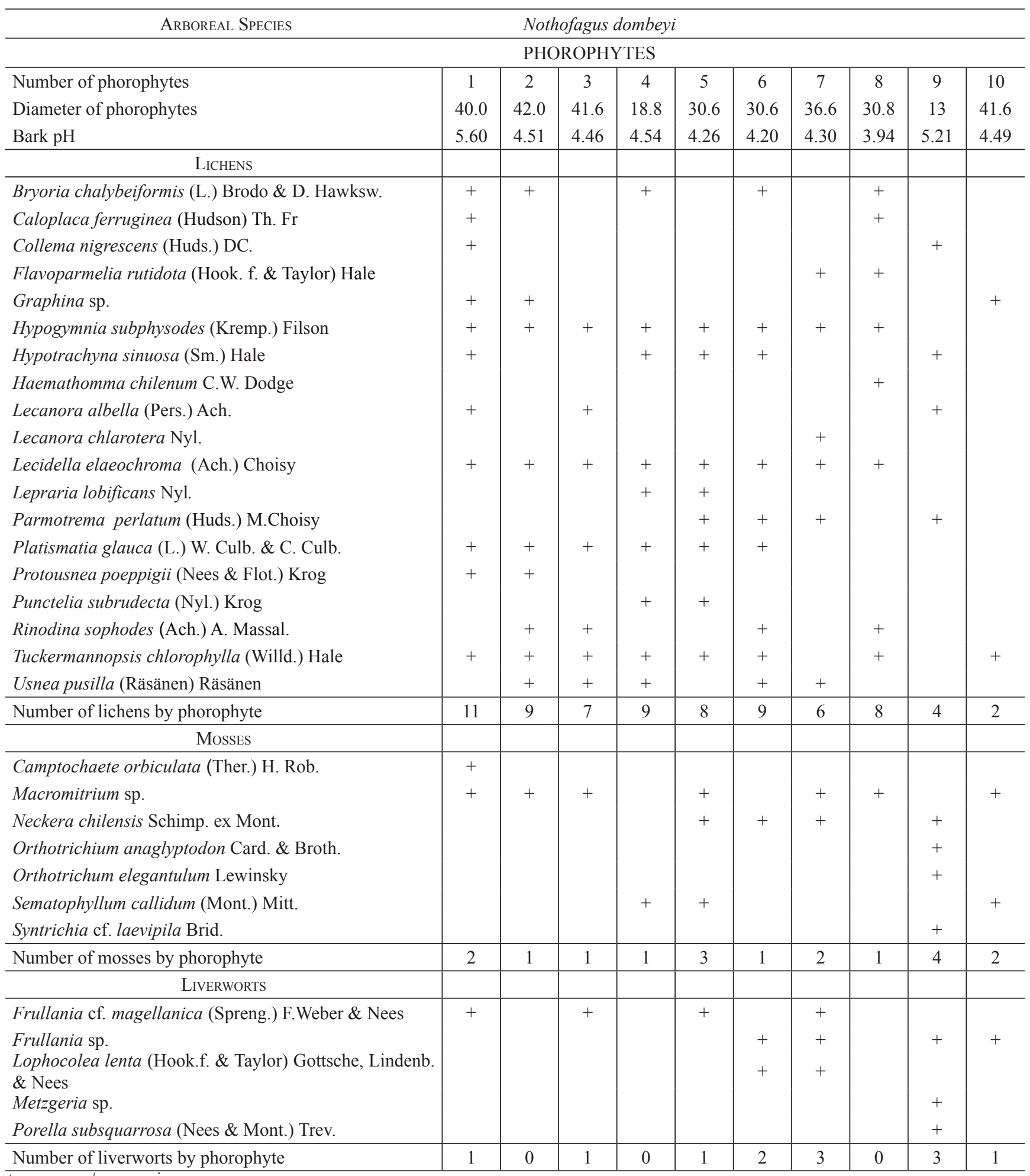

+: presence/ presencia 
TABLA IV. Relationship among richness lichen and bryophytes, bark pH and diameter of phorophytes in Nothofagus obliqua in the Protected Area, "Altos de Lircay" National Reserve.

TABLA IV. Relación entre la riqueza de líquenes y briófitos, pH de la corteza y diámetro de los forófitos en Nothofagus obliqua en el área protegida "Reserva Nacional Altos de Lircay".

\begin{tabular}{|c|c|c|c|c|c|c|c|c|c|c|}
\hline ARboreal Species & \multicolumn{10}{|c|}{ Nothofagus macrocarpa } \\
\hline \multicolumn{11}{|c|}{ PHOROPHYTES } \\
\hline Number of phorophytes & 1 & 2 & 3 & 4 & 5 & 6 & 7 & 8 & 9 & 10 \\
\hline Diameter of the phorophytes & 18.5 & 18.2 & 18.6 & 22.6 & 19.7 & 21.3 & 15.2 & 23.5 & 19.6 & 22.8 \\
\hline Bark pH & 5.08 & 5.64 & 5.53 & 5.90 & 5.50 & 5.44 & 5.33 & 5.67 & 5.65 & 5.63 \\
\hline \multicolumn{11}{|l|}{ LÍCHENS } \\
\hline Bacidia rubella (Hoffm.) Massal. & & & + & & + & & & & & \\
\hline Bulbothrix isidiza (Nyl.) Hale & + & + & + & + & + & + & + & & + & + \\
\hline Caloplaca ferruginea (Hudson) Th. Fr. & + & + & + & + & + & + & + & & + & + \\
\hline Collema nigrescens (Huds.) DC. & & + & & + & + & + & + & + & + & + \\
\hline Flavoparmelia rutidota (Hook. f. \& Taylor) Hale & & + & + & + & + & + & + & + & + & + \\
\hline Haemathomma chilenum C.W. Dodge & & & + & + & + & + & & + & + & + \\
\hline Hypotrachyna sinuosa (Sm.) Hale & & & & & + & & + & & & \\
\hline Lecanora albella (Pers.) Ach. & + & + & + & + & + & + & + & + & + & + \\
\hline Lecanora argentata (Ach.) Malme & & & + & + & + & + & & & & + \\
\hline Lecanora chlarotera Nyl. & & & + & + & + & + & & & & + \\
\hline Lecidella elaeochromma (Ach.) Choisy & + & + & + & + & + & + & + & + & + & + \\
\hline Melanelia subglabra (Räsänen) Essl. & & + & & & & + & & & & + \\
\hline Parmotrema perlatum (Huds.) M.Choisy & + & + & & + & & + & + & + & & + \\
\hline Pseudocyphellaria nudata (Zahlbr.) D. J. Galloway & & & + & + & & & & + & & \\
\hline Ramalina chilensis Bertero ex Nyl. & & & & & & & & & & + \\
\hline Ramalina farinacea (L.) Ach. & & & & & + & & + & + & & \\
\hline Rimelia reticulata (Taylor) Hale \& Fletcher & & & & + & & & + & & & \\
\hline Tuckermannopsis chlorophylla (Willd.) Hale & + & & & & & & & & & \\
\hline Usnea pusilla (Räsänen) Räsänen & & & & & + & + & + & & + & + \\
\hline Number of lichen by phorophyte & 6 & 8 & 10 & 12 & 13 & 12 & 11 & 8 & 8 & 13 \\
\hline \multicolumn{11}{|l|}{ Mosses } \\
\hline Brachythecium paradoxum (Hook.f. \& Wilson) A.Jaeger & & & & & & & & & & + \\
\hline Macromitrium sp. & & & & & & + & + & & & \\
\hline Neckera chilensis Schimp. ex Mont. & & & & & & & & & + & \\
\hline Orthotheciella varia (Hedw.) Ochyra & & & & & + & & & & & \\
\hline Orthothecium anaglyptodon Card. \& Broth. & + & & & & & + & + & & + & \\
\hline Orthotrichum bartramii Will. & & & & & & + & & & & \\
\hline Orthotrichum elegantulum Mitt & + & & + & & + & + & + & + & + & \\
\hline Orthothecium sp. & & & + & & & & & & & \\
\hline Syntrichia anderssonii (Ångstr.) R.H.Zander. & & & & & + & & & + & & \\
\hline Syntrichia cf. laevipila Brid. & & & & + & & & & & + & \\
\hline Syntrichia saxicola (Card.) Zand. & & & & & + & & & + & & + \\
\hline Number of mosses by phorophyte & 2 & 0 & 2 & 1 & 4 & 4 & 3 & 3 & 4 & 2 \\
\hline \multicolumn{11}{|l|}{ LIVERWORTS } \\
\hline $\begin{array}{l}\text { Frullania sp. } \\
\text { Lophocolea lenta (Hook.f. \& Taylor) Gottsche, Lindenb. } \\
\text { \& Nees }\end{array}$ & + & & & & + & & & + & & $\begin{array}{l}+ \\
+ \\
+\end{array}$ \\
\hline Number of liverworts by phorophyte & 1 & 0 & 0 & 0 & 1 & 0 & 0 & 1 & 0 & 2 \\
\hline
\end{tabular}




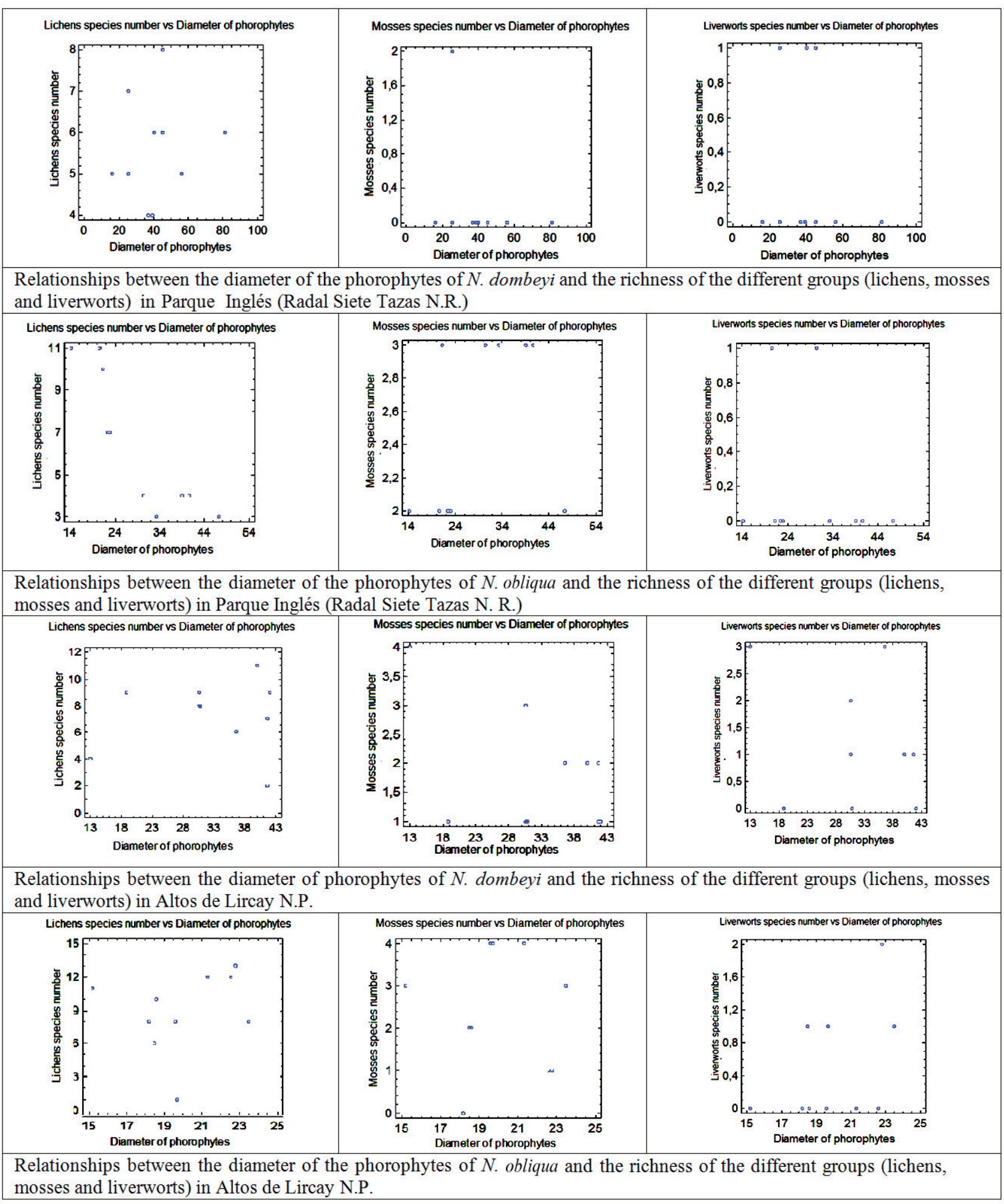

FIGURE 3: Relationships between the diameter of phorophytes of $N$.dombeyi and N. obliqua in both localities versus richness of the different groups (lichens, mosses and liverworts) analysed.

FiguRa 3: Relación entre el diámetro de forófitos de $N$. dombeyi y $N$. obliqua en ambas localidades versus riqueza de los diferentes grupos (líquenes, musgos y hepáticas) analizados. 
Thus, these species could be indicators of the undisturbed environmental conditions while the later appearance of nitrophytic species could be considered as a reflection of an environmental change, thus making possible its evaluation. Our results allow the conclusion that tree species and tree bark $\mathrm{pH}$ are the most important variables explaining epiphytic bryophyte and lichen composition and richness. Our results agree with those noted by Gustaffsson \& Ericksson (1995) and Mezaka et al. (2012).

Regarding to the lichen species found on N. obliqua bark, such as Lecanora chlarotera, Lecidella elaeochroma and Physcia adscendens, they seem to be species with a wide range of tolerance to $\mathrm{pH}$, as noted by Öztürk \& Oran (2011).

The results showed that the bark $\mathrm{pH}$ affect the establishment of epiphytic lichen species on these two Nothofagus species, nevertheless, in other studies it has been shown that this is not the only factor that could affect the distribution of epiphytic lichen in these Nothofagus species (Pereira \& San Martín 1998, Pereira et al. 1999).

The low number of bryophytes (mosses and liverworts) observed on phorophytes of both tree species of the two localities studied and the lack of specificity by a particular tree species, could suggest that the bryophytes found in this study have a range of tolerance at $\mathrm{pH}$ higher to the lichens. The establishment of bryophytes and lichens not only could be correlated with the $\mathrm{pH}$ but also with age, the number of growth anomalies, texture and moisture available in the phorophytes (Brodo et al. 2001, Öztürk \& Oran 2011).

The moss richness on $N$. obliqua is higher that on $N$. dombeyi, while that of the liverworts is slightly higher on $N$. dombeyi than on $N$. obliqua, in both localities. The major richness of moss in $N$. obliqua could correspond to a major tolerance to $\mathrm{pH}$ and the major richness of the liverworts in $N$. dombeyi to a major affinity to trees with lightly acid bark $\mathrm{pH}$, where these latter are more abundant.

In spite of that the age of the phorophytes was not the target of this study, it must be mentioned that due to narrow range of diameter of the phorophytes analysed, it was not possible to establish if there is any type of correlation between the age of the phorophytes of the two tree species studied and bryophytes and lichens richness (Fig.3). Others works revealed a significant correlation between these parameters in others species of Nothofagus (Caldiz 2005, Pereira et al. 1999, Pereira \& San Martín 1998), therefore, it suggests to conduct studies that allow to relate these two variables and to establish if this factor really can influence also in the establishment of bryophytes and lichens in these two tree species.

\section{ACKNOWLEDGEMENTS}

The authors would like to thanks to DAAD and to the University of Talca for economic support to carry out this work. Also we would like to thank the help giving by Dr. Peter Caligari in the revision of the English of this manuscript.

\section{REFERENCES}

Aude, E. \& R.S. Poulden. 2000. Influence of management on the species composition of epiphytic cryptogams in Danish forests. Applied Vegetation Science 3: 81-88.

Barkman, J. 1958. Phytosociology and Ecology of Cryptogamic epiphytes. Van Gorcum. Assen, Holanda. xiii +628 pp.

Brodo, I.M., S.D. Sharnoff \& S. Sharnoff. 2001. Lichens of North America. Yale University Press, New Haven and London. 795 pp.

CALdiz, M. 2005. Diversity and growth of epiphytic macrolichens in northwestern Patagonian Nothofagus, forests. Doctoral Thesis, Swedish University of Agricultural Sciences Almarp. 34 pp.

Gustafsson, I. \& I. ERIKSson. 1995. Factors of importance for the epiphytic vegetation of aspen Populus tremula with special emphasis on bark chemistry and soil chemistry. Journal Applied Ecology 32: 412-424.

Kuusinen, M. 1996. Epiphyte Flora and Diversity on Basal Trunks of Six Old-Growth Forest Tree Species in Southern and Middle Boreal Finland. The Lichenologist 28: 443-463.

Hawksworth, D.L. \& D.L. HiLl. 1984. The lichen-forming fungi. Blackie, Glasgow \& London, 158 pp.

Ihlen, P.G., I. GJerde \& M. SAetersdal. 2011. Structural indicators of richness and rarity of epiphytic lichens on Corylus avellana in two different forest types within a nature reserve in south-western Norway. Lichenologist 33: 215229.

Jüriado, I., J. LiIra, J. PaAl \& A. SuiJa. 2009. Tree and stand level variables influencing diversity of lichens on temperate broad-leaved trees in boreo-nemoral floodplain forests. Biodiversity Conservation 18: 105-125.

Larsen, R.S., J.N.B. Bell, P.W. James, P.J. Chimonides, F.J. Rumsey, A. Tremper \& O.W. Purvis. 2006. Lichen and bryophyte distribution on oak in London in relation to air pollution and bark acidity. Environmental Pollution 146: 332-340.

Mezger, U. 1996. Biomonitoring mit epilithischen und epiphytischen Flechten in einem Belastungsgebiet (Berlin). Ein Verfahrensvergleich. Bibliotheca Lichenologica 63: 1-164.

Mezaka, A., G. Brumelis \& A. Pireräns. 2008. The distribution of epiphytic bryophyte and lichen species in relation to phorophyte characters in Latvian natural old-growth broad leaved forests. Folia Cryptogamica Estonica 44: 89-99.

Mezaka, A., G. Brumelis \& A. Piteräns. 2012. Tree and stand. Scale factors affecting richness and composition of epiphytic bryophytes and lichens in deciduous woolland key habitats. Biodiversity and Conservation 21: 32213241 .

Müller, F. \& I. Pereira. 2006. The bryophyte flora of nature reserves in central Chile. 1. The moss flora of Los Ruiles Nature Reserve, near Talca. Tropical Bryology 27: 55-66.

ÖZTÜRK, S. \& S. ORAN. 2011. Investigations on the bark pH 
and epiphytic lichen diversity of quercus taxa found in Marmara region. Journal of Applied Biological Sciences 5: 27-33.

Pereira, I. \& J. SAn Martín. 1998. Flora liquénica corticícola en un bosque caducifolio de Nothofagus alesandrii de Chile Central. Cryptogamie, Bryologie. Lichénologie 19(1): 5972.

Pereira, I., J. San Martín \& C. Roux. 1999. Patrón florístico de líquenes epífitos de Nothofagus glauca en un bosque costero de Chile Central. Gayana Botanica 56(2): 69-76.

Pereira, I., F. Müller \& A. Valderrama. 2006. Diversity and Distribution of bryophytes and lichens of El Colorado, Chile Central. Nova Hedwigia 83(1-2): 117-127.
SNäLl, T., A. Hagström, J. Rudolphi \& H. Rydin. 2004. Distribution pattern of the epiphyte Neckera pennata on three spatial scales - Importance of past landscape structure, connectivity and local conditions. Ecography 27: 757-766.

VAN HeRK, C.M. 2001. Bark pH and susceptibility to toxic air pollutants as independent causes of changes in epiphytic lichen composition in space and time. The Lichenologist 33: 419-442.

WALKER, F.J. \& P.W. JAMES. 1980. A revised guide to microchemical technique for the identification of lichen products. Bulletin British Lichen Society 46: 13-29 (Supplement).

Recibido: 23.11 .12

Aceptado: 15.01 .14 